\title{
O PAPEL DA LEGISLAÇÃO URBANÍSTICA NAS TRANSFORMAÇÕES DA PAISAGEM NAS BORDAS URBANAS DA CIDADE DE CAMPOS DOS GOYTACAZES/RJ
}

\author{
THE ROLE OF URBANISTIC LEGISLATION IN THE TRANSFORMATIONS OF THE LANDSCAPE \\ IN THE URBAN EDGE OF THE CITY OF CAMPOS DOS GOYTACAZES / RJ
}

\author{
Antonio Leandro Crespo de Godoy \\ Vera Regina Tângari
}

\begin{abstract}
Resumo
Campos dos Goytacazes, localizada na região Norte Fluminense, vivenciou nas duas últimas décadas significativas transformações na paisagem urbana, alavancadas pela dinâmica de distribuição de royalties e participações especiais da produção petrolífera e pela intensificação das atividades e investimentos do mercado imobiliário. A expansão da mancha urbana ocorre junto às mudanças no ordenamento de uso e ocupação do solo que contribuem para o processo de espraiamento e fragmentação urbana. $O$ objetivo desta pesquisa é analisar, por meio da elaboração de mapas temáticos, o papel da legislação urbanística nas transformações da paisagem nas bordas urbanas da cidade, relacionando a estrutura fundiária historicamente marcada por raízes coloniais, a legislação de uso e ocupação do solo e as transformações na paisagem ocorridas nas décadas de 2000 e 2010.
\end{abstract}

Palavras-chave: paisagem urbana. Uso e ocupação do solo. Royalties. Planejamento territorial urbano.

\section{Abstract}

Campos dos Goytacazes, located in the Northern Fluminense region, has experienced significant transformations in the urban landscape over the past two decades, leveraged by the dynamics of royalty distribution and special participation in oil production and by the intensification of activities and investments in the real estate market. The expansion of the urban spot occurs along with changes in the order of use and occupation of the soil that contribute to the spreading process and urban fragmentation. The objective of this research is to analyze, through the elaboration of thematic maps, the role of urban legislation in the transformations of the landscape in the urban edges of the city, relating the land structure historically marked by colonial roots, the legislation of use and occupation of the land and the transformations in the landscape that occurred in the 2000s and 2010s.

Keywords: Urban landscape. Land use and occupation. Royalties. Urban territorial planning. 


\section{Introdução}

A cidade de Campos dos Goytacazes figura como centro urbano do maior município, em extensão territorial, do estado do Rio de Janeiro, localizado na Região Norte Fluminense (Figura 1), com território de 4.031,989 km² e uma população essencialmente urbana, $90,3 \%$ de seus habitantes (IBGE, 2020). Considerada historicamente como polo regional, teve sua economia alavancada pelo ciclo de produção sucroalcooleira e posteriormente pela intensa atividade de extração do petróleo na Bacia de Campos.

O distrito sede é formado por dois subdistritos, divididos por uma fronteira natural, o Rio Paraíba do Sul. À margem sul do rio o subdistrito de Campos e à norte o de Guarus, esse último normalmente identificado como periferia, onde residem as parcelas populacionais de menor renda. Durante a formação e expansão do tecido urbano, ao longo do século XX, os planos e políticas de planejamento urbano trataram de forma desigual esses subdistritos. Na margem sul, o subdistrito de Campos foi objeto de grande parte dos planos urbanísticos e recebedor de maiores investimentos públicos. Na margem norte, o subdistrito de Guarus foi atendido com menos recursos e investimentos, por consequência, possui um tecido urbano menos estruturado, pois só tardiamente tornou-se objeto de intervenções urbanísticas relevantes. Diferentemente do ocorrido na margem sul, onde grande parte dos recursos hídricos foram aterrados ou drenados, ao ser menos contemplado pelos planos urbanísticos, Guarus, paradoxalmente, manteve grande parte destes recursos preservados (GODOY e ALIPRANDI, 2016). A mancha urbana da cidade se estende por uma extensa planície (Figura 2), fator preponderante na produção do tecido urbano, que pode ser definido como espraiado, extenso e permeado por grandes espaços livres não edificados ou urbanizados (MAGNOLI, 2006).

Considerada uma cidade de porte médio, a $277 \mathrm{~km}$ da capital fluminense, vivenciou nas duas últimas décadas um ciclo de grandes investimentos públicos e privados, alavancados pela dinâmica de distribuição de royalties e participações especiais da produção petrolífera. Isso impactou diretamente no orçamento público municipal e, com a abundância de recursos e investimentos públicos acompanhada da intensificação das atividades e investimentos do mercado imobiliário, tornam-se marcantes as grandes transformações da paisagem e a expansão da superfície da mancha urbana.

Ao observarmos a evolução orçamentária demostrada na Figura 3 , é possível perceber a significativa contribuição na receita corrente municipal que os royalties e participações especiais representam. Também podemos observar o aumento gradativo, proporcional ao aumento da receita corrente, em investimentos de infraestrutura pública, nas áreas de habitação e urbanismo; saúde e saneamento; e transportes, que impactam na produção do espaço urbano.

O crescimento populacional também foi significativo no período, considerando que as raízes da ocupação da planície campista remontam ao período colonial, atingindo a categoria de cidade em 1835, possuía, segundo censo da época, 51.718 habitantes, 18.423 na área urbana e 33.295 nas áreas rurais. Desses habitantes, 30.395 eram pessoas escravizadas (FEIDIT, 1979 apud OLIVEIRA, 2012). O município atingiu 389.109 habitantes em 1991, 463.731 apurados pelo censo em 2010, e população estimada de 511.168 habitantes em 2020 (IBGE 1991/2010/2020). Esse acréscimo de 122.059 habitantes em três décadas representa a decadência da indústria sucroalcooleira, acompanhada de grande êxodo rural da região, e do novo ciclo econômico proporcionado pela extração de petróleo na Bacia de Campos. É possível notar, nos dados apresentados na Figura 4, comparando a evolução populacional campista em relação às curvas apresentadas pelo estado do Rio de Janeiro e pelo Brasil, uma significativa diferença no padrão. A evolução das proporções entre as populações rurais e urbanas do município em relação ao estado e ao país demonstra o impacto da realidade de uma agroindústria fundamentada na monocultura que se torna decadente, em contraponto à atividade emergente, a indústria de extração do petróleo na Bacia de Campos.

Objetivando uma análise da distribuição da população pelo território, o mapa da Figura 5 foi elaborado com dados do Censo IBGE (2010), conforme a legenda, quanto mais escuras as cores, maior é a renda mensal nominal média e quanto mais claras, menor. É possível verificar um processo de estratificação urbana entre centro e periferia quando o padrão de renda é analisado: os setores 


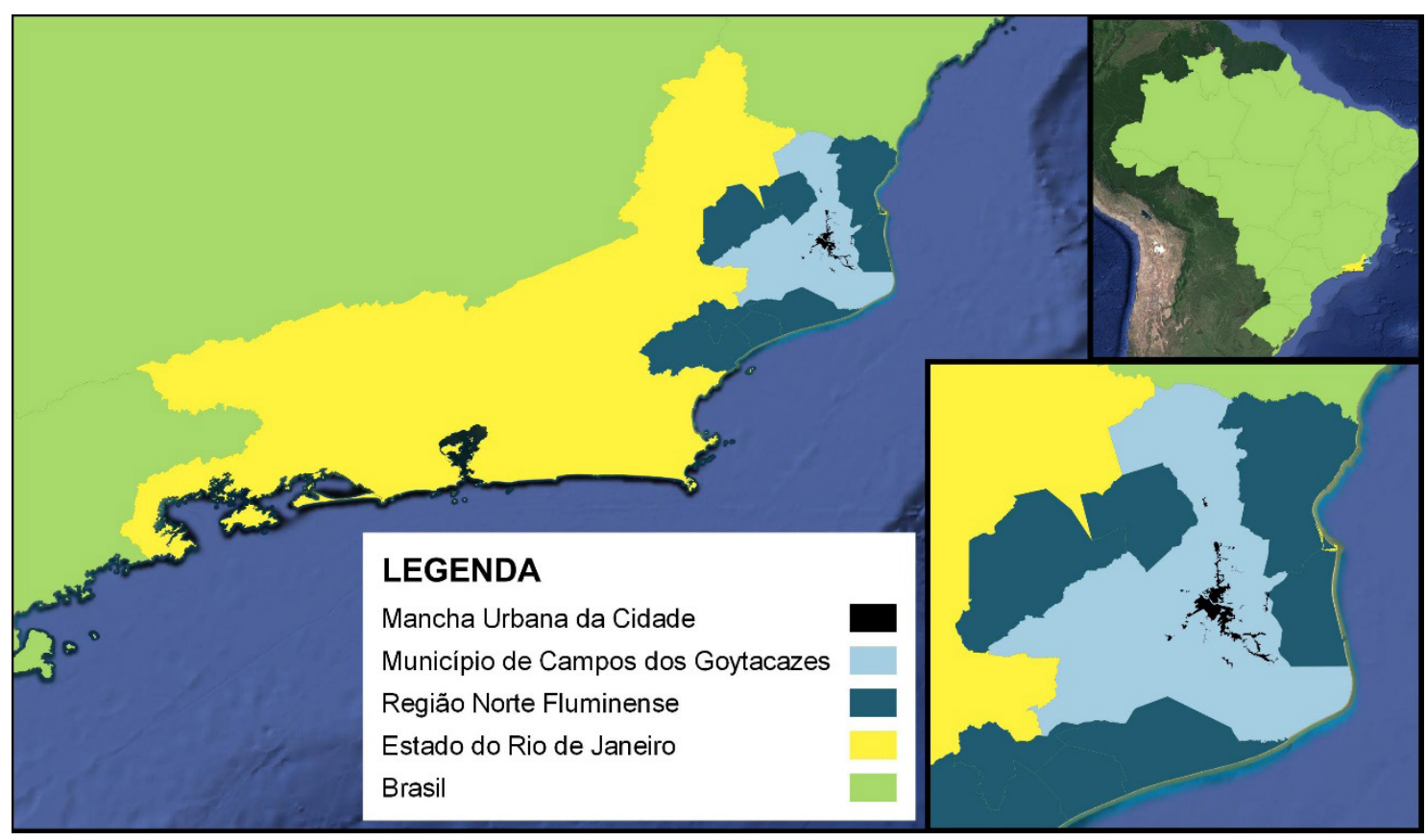

Figura 1: Localização

Mapa de localização de Campos dos Goytacazes, representando conforme a legenda a mancha urbana do Distrito Sede, o Município, a Região Norte Fluminense, o Estado do Rio de Janeiro e o Brasil.

Fonte: Elaborado pelos autores (2021) com dados de IBGE (2020) sobre imagem Google Satélite (2020)

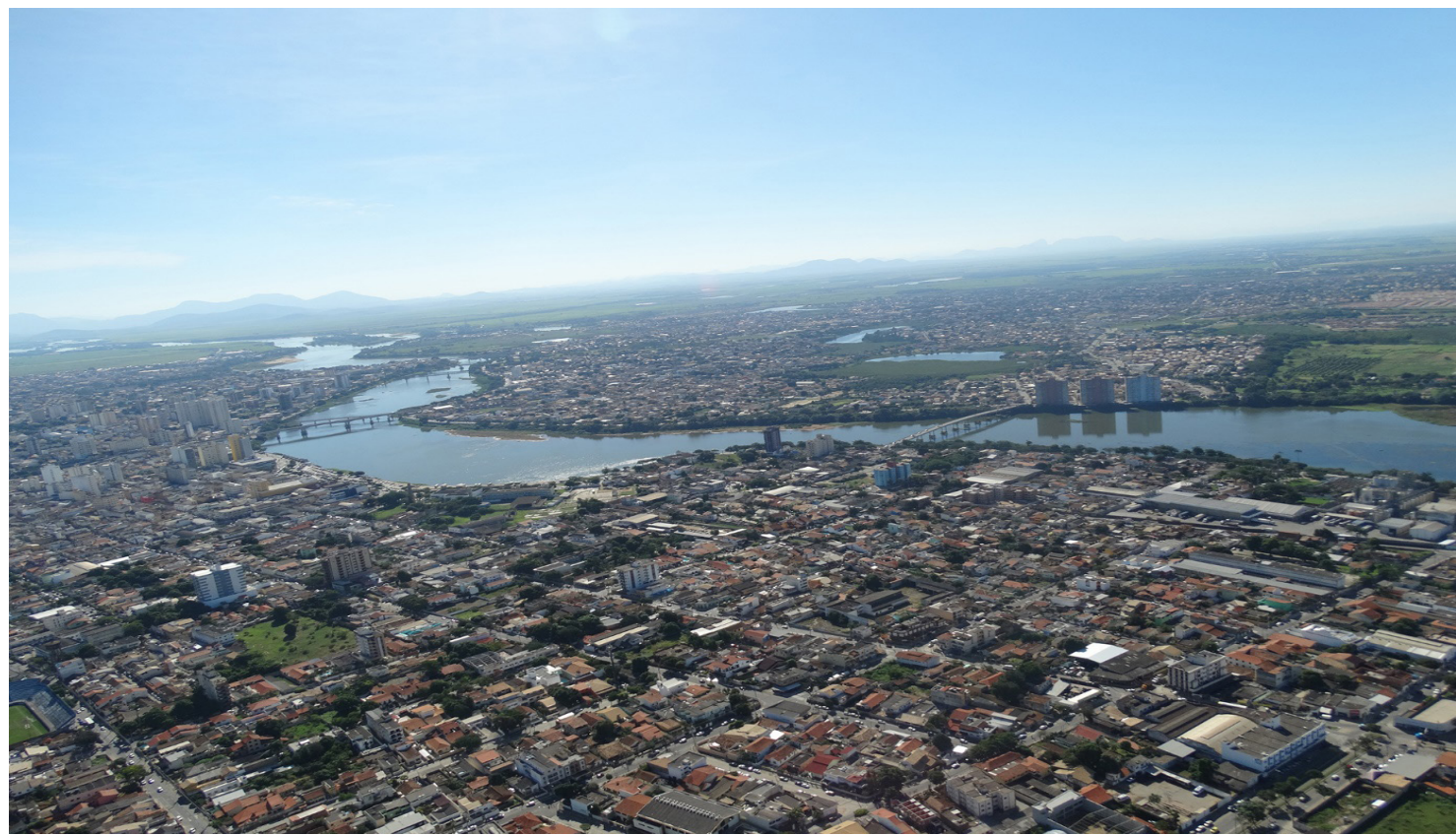

Figura 2: Paisagem Campista

Vista aérea da cidade de Campos dos Goytacazes, o subdistrito de Campos abaixo (margem sul do rio) e o subdistrito de Guarus acima (margem norte do rio).

Fonte: Oficina QUAPA-SEL, Campos dos Goytacazes (2015). 


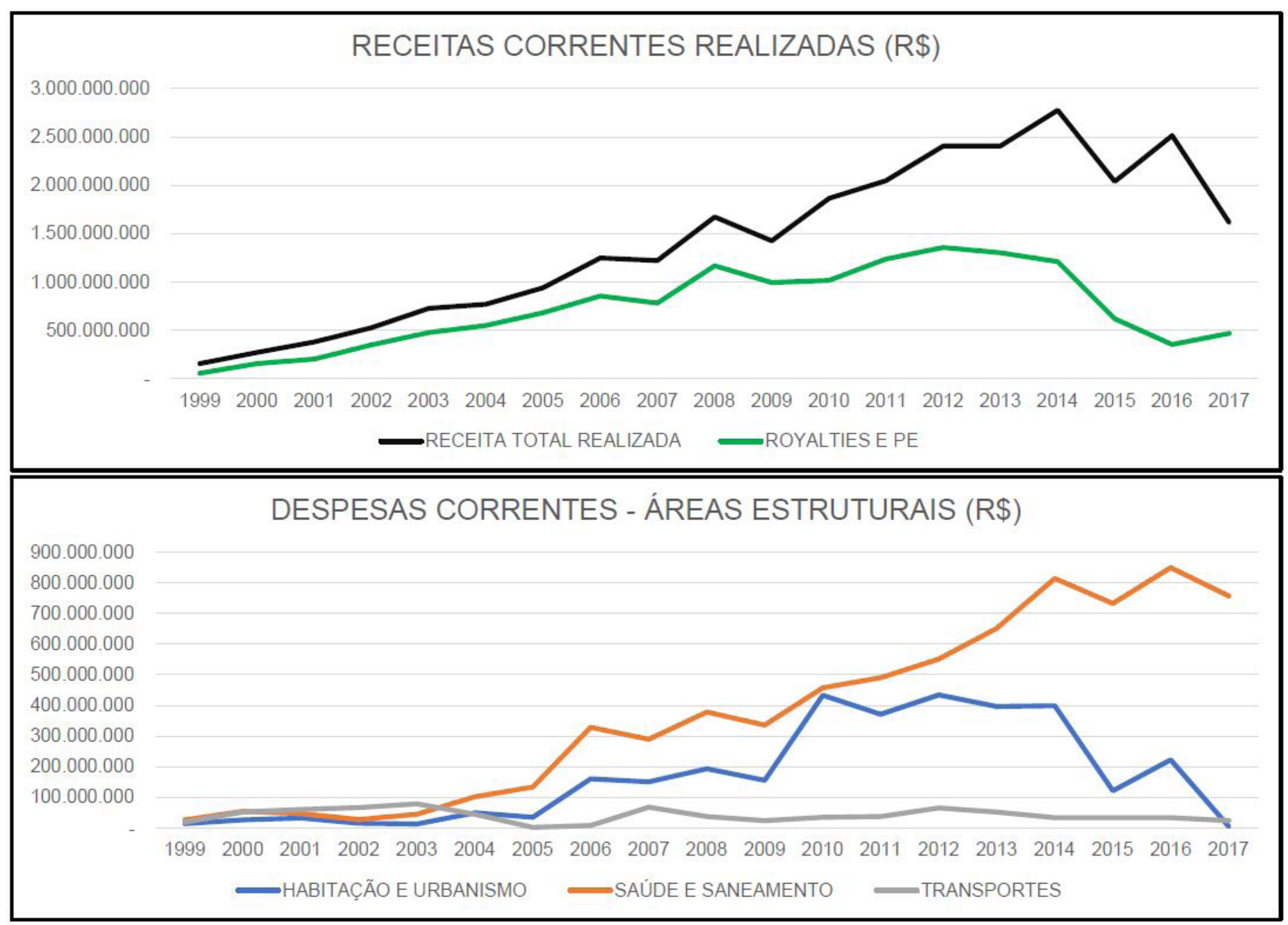

Figura 3: Evolução do orçamento público municipal

Receitas e Despesas Correntes - Campos dos Goytacazes.

Fonte: Elaborado pelos autores com dados do TCE-RJ, Info Royalties e Compara Brasil, 2020. 


\begin{tabular}{|c|c|c|c|c|c|c|}
\hline \multicolumn{7}{|c|}{ EVOLUÇÃO POPULACIONAL RURAL/URBANA (BRASIL-ESTADO DO RIO DE JANEIRO-CAMPOS DOS GOYTACAZES) } \\
\hline \multicolumn{7}{|c|}{ Brasil } \\
\hline ANO & Total & $\begin{array}{c}\text { População } \\
\text { Rural }\end{array}$ & $\%$ & $\begin{array}{c}\text { População } \\
\text { Urbana }\end{array}$ & $\%$ & \multirow{9}{*}{ 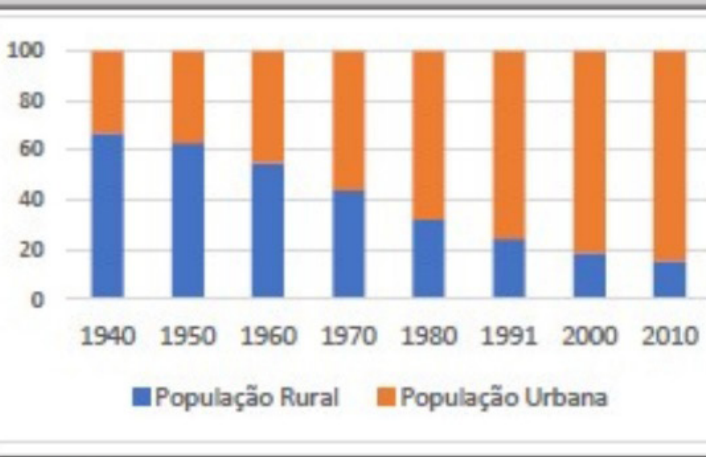 } \\
\hline 1940 & 41.236 .315 & 27.652 .832 & 67 & 13.583 .483 & 33 & \\
\hline 1950 & 51.944 .397 & 32.746 .711 & 63 & 19.197 .686 & 37 & \\
\hline 1960 & 70.992 .343 & 38.987 .526 & 55 & 32.004 .817 & 45 & \\
\hline 1970 & 93.134 .846 & 41.037 .586 & 44 & 52.097 .260 & 56 & \\
\hline 1980 & 119.011 .052 & 38.573 .725 & 32 & 80.437 .327 & 68 & \\
\hline 1991 & 146.825 .475 & 35.834 .485 & 24 & 110.990 .990 & 76 & \\
\hline 2000 & 169.799 .170 & 31.845 .211 & 19 & 137.953 .959 & 81 & \\
\hline 2010 & 190.755 .799 & 29.829 .995 & 16 & 160.925 .804 & 84 & \\
\hline \multicolumn{7}{|c|}{ Estado do Rio de Janeiro } \\
\hline ANO & Total & $\begin{array}{c}\text { População } \\
\text { Rural }\end{array}$ & $\%$ & $\begin{array}{c}\text { População } \\
\text { Urbana }\end{array}$ & $\%$ & \multirow{9}{*}{ 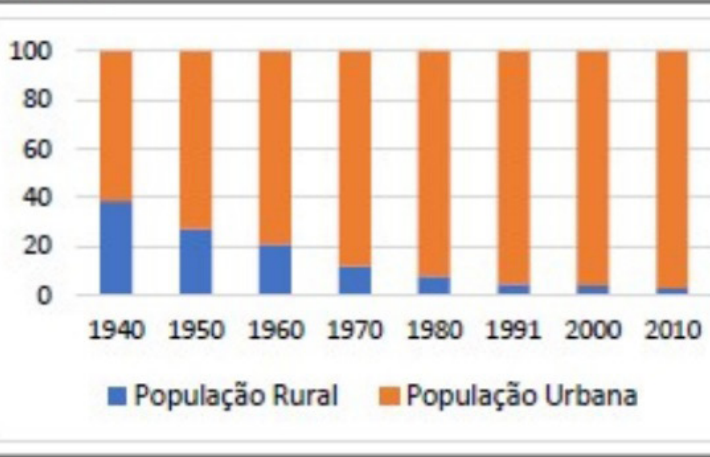 } \\
\hline 1940 & 3.611 .998 & 1.399 .787 & 39 & 2.212 .211 & 61 & \\
\hline 1950 & 4.739 .353 & 1.292 .546 & 27 & 3.446 .807 & 73 & \\
\hline 1960 & 6.709 .891 & 1.409 .262 & 21 & 5.300 .629 & 79 & \\
\hline 1970 & 8.994 .802 & 1.088 .184 & 12 & 7.906 .618 & 88 & \\
\hline 1980 & 11.291 .631 & 923.244 & 8 & 10.368 .387 & 92 & \\
\hline 1991 & 12.807 .706 & 608.065 & 5 & 12.199 .641 & 95 & \\
\hline 2000 & 14.391 .282 & 569.816 & 4 & 13.821 .466 & 96 & \\
\hline 2010 & 15.989 .929 & 525.690 & 3 & 15.464 .239 & 97 & \\
\hline \multicolumn{7}{|c|}{ Municipio de Campos dos Goytacazes } \\
\hline ANO & Total & $\begin{array}{c}\text { População } \\
\text { Rural }\end{array}$ & $\%$ & $\begin{array}{c}\text { População } \\
\text { Urbana }\end{array}$ & $\%$ & \multirow{9}{*}{ 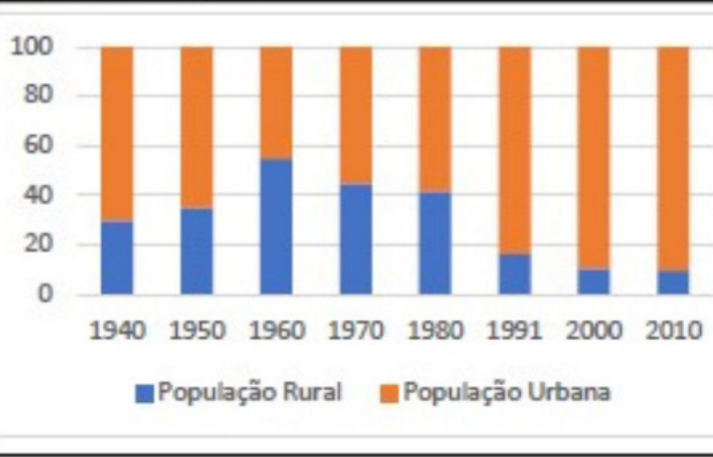 } \\
\hline 1940 & 223.373 & 66.644 & 30 & 156.729 & 70 & \\
\hline 1950 & 237.633 & 83.088 & 35 & 154.545 & 65 & \\
\hline 1960 & 292.292 & 160.318 & 55 & 131.974 & 45 & \\
\hline 1970 & 318.806 & 142.724 & 45 & 176.082 & 55 & \\
\hline 1980 & 348.542 & 145.184 & 42 & 203.358 & 58 & \\
\hline 1991 & 389.109 & 64.442 & 17 & 324.667 & 83 & \\
\hline 2000 & 406.989 & 42.812 & 11 & 364.177 & 89 & \\
\hline 2010 & 463.731 & 45.006 & 10 & 418.725 & 90 & \\
\hline
\end{tabular}

Figura 4: Dados Populacionais

Comparação entre dados populacionais municipais, estatuais e nacionais.

Fonte: Elaborado pelos autores com dados do IBGE (1991/2000/2010); IBGE. Anuário Estatístico do Brasil. VIII-1947/XII-1951/ XXII-1961; IBGE-SIDRA 2020; IBGE Anuário Geográfico do Estado do Rio de Janeiro 1961. 


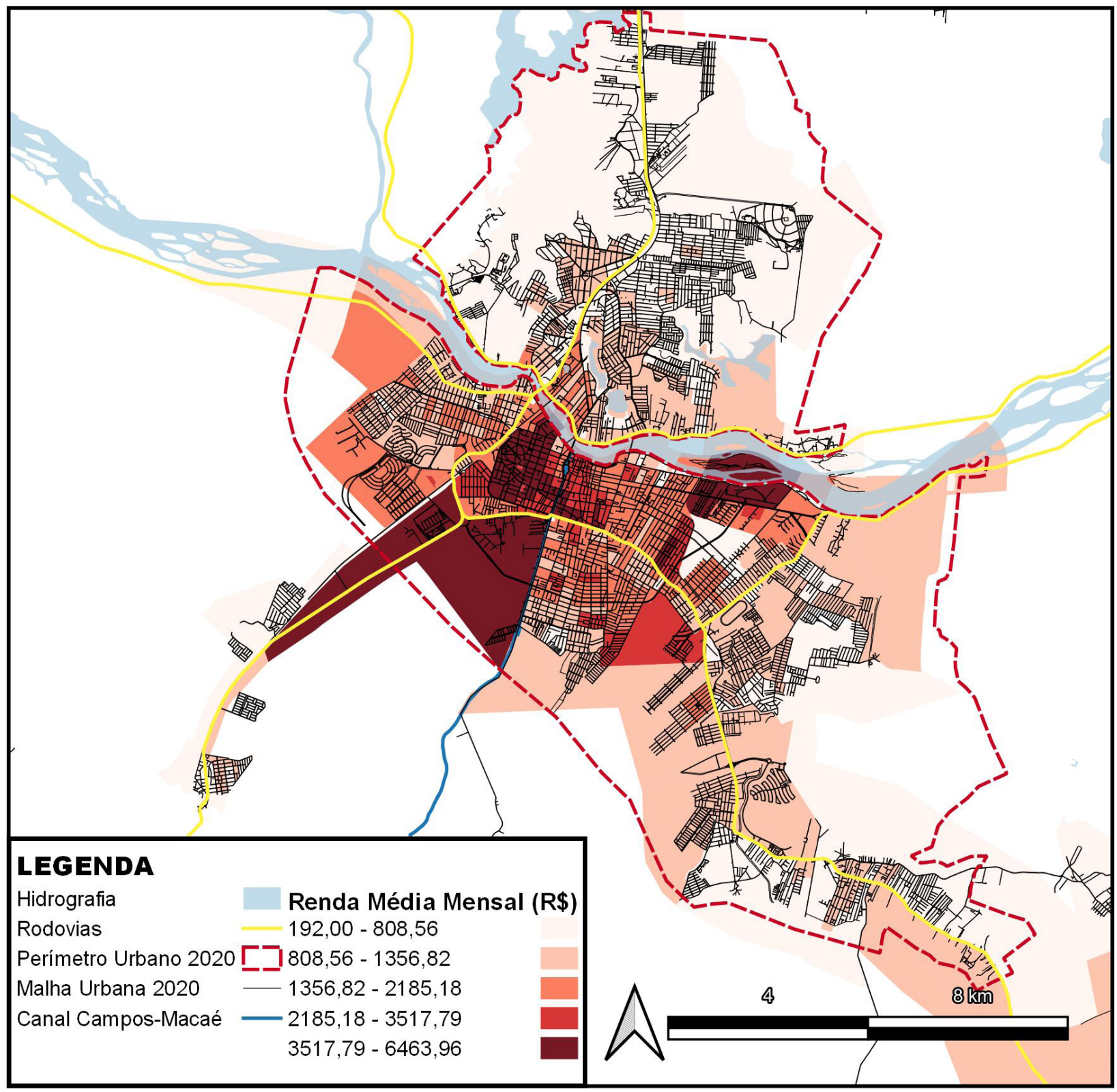

Figura 5: Mapa de renda média

Mapa de renda média por setor censitário (Responsáveis por domicílios).

Fonte: Elaborado pelos autores com dados do IBGE (2010) e Google Earth (2020) 
central e oeste da cidade apresentam rendas mais elevadas; o setor norte, rendas menores; e o setor sudeste apresenta padrões de renda variada conforme o distanciamento do centro.

A decadência da produção sucroalcooleira no munícipio, intensificada a partir da década de 1980, produziu grande êxodo rural e aumentou a demanda habitacional na cidade. Considerada a principal atividade econômica do município desde meados do século XVIII, a agroindústria canavieira campista, que já contou com vinte usinas, atualmente conta com apenas duas em funcionamento. Se a atividade econômica canavieira configurou o espaço do município por tanto tempo em uma zona urbana, onde se instalavam a cidade e suas funções, circundadas pela zona rural e dedicada em maior parte à monocultura, sua decadência tornou disponível a ocupação urbana das antigas propriedades rurais (ZACCHI, 2012; FARIA, ZACCHI, MOTHÉ, 2013), que atenderam convenientemente à demanda por investimento imobiliário característico do cenário econômico brasileiro no período.

Paralelo à promulgação do Estatuto da Cidade, o cenário brasileiro do início do século XXI abarca um novo paradigma para o mercado imobiliário, que pode ser considerado propício, resultando em empresas de capital aberto, como Cardeman (2014) aponta, em três principais fatores que alavancam as atividades imobiliárias: controle da inflação, a queda das taxas de juros e a alienação fiduciária. Com uma significativa entrada de investimento externo diante da melhoria da economia nacional, o período foi caracterizado por um ambiente de baixa de juros e estabilidade econômica, ampliação do crédito, inclusive para a aquisição de bens imóveis. "No mercado imobiliário tornou-se também necessário o aumento da oferta de unidades habitacionais para atender às classes sociais com maior poder de compra e facilidades de crédito, que puderam começar a adquirir este tipo de bem" (CARDEMAN, 2014, p. 28). Também é na primeira década deste século que boa parte das cidades brasileiras implementam modificações em suas legislações de uso e ocupação do solo, principalmente por meio dos Planos Diretores Municipais, como é o caso de Campos dos Goytacazes.

O objetivo deste artigo é analisar o papel da legislação urbanística de uso e ocupação do solo nas transformações da paisagem nas regiões de borda do tecido urbano na cidade de Campos dos Goytacazes. Com o crescimento significativo da receita pública, seguido do aumento de sua população urbana e a intensificação da atividade imobiliária, a expansão urbana se dá convertendo terras rurais em urbanas com a construção de uma legislação de uso e ocupação do solo que favorece esse processo e reforça a estrutura fundiária. As grandes propriedades, terras remanescentes das antigas usinas de produção sucroalcooleira, são incorporadas ao perímetro urbano legalmente delimitado, com grande valorização imobiliária, tornando-se objeto de especulação.

Conforme nos mostram Macedo et al. (2018), não se pode considerar que as cidades brasileiras têm uma forma urbana padrão, cada mancha urbana, inserida no suporte físico, proporcionará uma paisagem diferente. Os autores definem mancha urbana como a área contida dentro do perímetro de uma urbanização, de portes diversos de acordo com sua dimensão. A leitura da mancha urbana campista, sobre o suporte de sua extensa planície, foi realizada a partir da elaboração de mapas temáticos, relacionando a estrutura fundiária característica da cidade com a legislação de uso e ocupação do solo e as transformações da paisagem ocorridas nas décadas de 2000 e 2010. Esse recorte temporal se justifica pelo marco legal que configura a mudança na realidade orçamentária do município, a Lei Federal n 9.478 de 1997, "Lei do Petróleo", que inaugura o ciclo de investimentos de que trata a pesquisa e a intensidade das transformações da paisagem.

Por essa razão, para que seja possível a compreensão desse processo, fez-se imprescindível adotar o conceito de paisagem segundo Macedo (2015), que a considera como:

"[...] expressão morfológica das diferentes formas de ocupação e, portanto, de transformação do ambiente em um determinado tempo. A paisagem é considerada então como um produto e como um sistema. Como um produto porque resulta de um processo social de ocupação e gestão de determinado território. Como um sistema porque, na medida em que qualquer ação for impressa, com certeza haverá uma reação correspondente, a qual 
equivale ao surgimento de uma alteração morfológica parcial ou total" (MACEDO, 2015. p. 15).

Portanto, a paisagem, sistema e produto resultante dos processos de ocupação socioespacial, é objeto complexo, fruto da ação humana, e também segundo o cenário econômico, social, ambiental e político, torna-se expressão morfológica da disputa histórica dos diversos interesses que tencionam as relações sociais e políticas. Assim, Santos (2002), ao abordar a questão do território brasileiro, traz a reflexão sobre a inexistência de espaços vazios, ou seja, todo o território é ocupado por dados atuais, seja em um mundo já concreto ou mesmo no âmbito das intenções. O autor afirma que o Estado e o capital estão em toda parte, mesmo que de forma diferenciada. Ele considera que o território deve ser observado em suas fronteiras jurídico-políticas, heranças históricas e, sobretudo, sobre o conteúdo econômico, financeiro, fiscal e normativo. Nesse sentido, é correto afirmar que não há "espaços vazios" dentro do perímetro urbano de uma cidade, ou seja, um espaço livre de edificações ou urbanização, uma gleba inserida no perímetro urbano, se não está ocupada concretamente, está ocupada no âmbito das intenções, objeto de especulação imobiliária, campo de disputa, objeto de relações de poder. Isso evidencia o papel que os diversos agentes públicos e privados possuem nesta dinâmica de relações sociais e de poder e a importância do entendimento desse conceito para esta pesquisa. Ou seja, se os territórios resultam das dinâmicas sociais que, por sua vez, estão relacionadas aos agentes públicos e privados, é fundamental o estudo da ação desses agentes nas áreas urbanas, onde essa dinâmica é mais intensa.

Conforme aponta Reis (2015), nas décadas finais do século XX e nas primeiras do século XXI, são características as formas de urbanização marcadas pela dispersão urbana. Para o autor, não se trata apenas de um fenômeno brasileiro, mas é um movimento típico de países de economia avançada e de emergentes, em todos os continentes. Dessa forma, Coelho (2016) define a urbanização dispersa como um processo de:

"[...] criação de descontinuidades das partes edificadas no território, geralmente com baixas densidades construti- vas, em áreas originalmente rurais ou naturais, mantendo interstícios em relação aos núcleos de urbanização contínuos adjacentes e decorrentes da difusão do modo de vida urbano, de forma interconectada funcionalmente" (COELHO, 2016, p. 5).

O processo de expansão urbana da cidade de Campos dos Goytacazes também pode ser definido como um processo de espraiamento, entendendo esse conceito como o crescimento urbano que ocorre sob forma de expansão horizontal, com adição de novas áreas urbanizadas e em direção a setores periféricos, com padrão de ocupação não denso e permeado por espaços livres de edificação dentro do solo urbano. Esse processo de crescimento espraiado potencializa a proliferação de subúrbios, condomínios horizontais fechados e conjuntos habitacionais nas periferias da cidade e aprofunda processos de segregação das funções e serviços urbanos (NADALIN e IGLIORI, 2015; NANDIN, 2013; SANTOS JUNIOR, 2001).

\section{A Questão Fundiária}

Para compreender a produção do solo urbano de Campos dos Goytacazes é de grande relevância o entendimento de sua estrutura fundiária. A cidade foi crescendo a partir da ocupação de antigas fazendas de produção de cana-de-açúcar, grandes propriedades rurais de um número reduzido de proprietários. De forma geral, tais proprietários, como explicita Capel (2013), atuam significativamente na conversão de áreas rurais em terrenos urbanos, tornando-se agentes proeminentes do processo de urbanização. $\mathrm{O}$ autor ressalta que a terra urbana tem status de mercadoria especial, considerando sua localização fixa e intrasferível e sua natureza essencial e permanente. Além das consequências do valor do solo na ação humana em forma de infraestrutura, investimentos ou planejamento urbano, a propriedade do solo passa a ser também um capital especial, um capital territorial.

Assim, foram sendo formados na cidade de Campos dos Goytacazes, em meio à expansão da mancha urbana, diversos espaços livres de edificação e de urbanização, correspondendo a glebas remanescentes de terras de usinas de produção sucroalcooleira, de 
propriedade de fazendeiros e de investidores. Diversas propriedades rurais foram, ao longo das décadas de expansão, incorporadas ao perímetro urbano da cidade e configuraram o espaço urbano (CONTI, 2013).

É possível observar no mapa da Figura 6 a configuração dessa estrutura fundiária, atentando para o avanço gradativo do perímetro urbano com os planos diretores de 1991, 2008 e 2020, incluindo, a cada novo alargamento de suas dimensões, terras das antigas usinas São João, São José, Santo Antônio, Queimado, Cambaíba, Santa Cruz e Sapucaia, além de propriedades de antigas fazendas e de atuais investidores. Dessa forma, os perímetros urbanos delimitados pelas linhas tracejadas em preto (1991), amarelo (2008) e vermelho (2020) constituíram sempre uma região de borda da cidade, não urbanizada, mas incluída generosamente como grandes extensões de espaços livres de edificação e de urbanização, terras reservadas à expansão da cidade, pertencentes a um número reduzido de grandes proprietários, convertidas automaticamente de terras rurais em glebas urbanas. A constante expansão urbana da cidade atende a interesses de valorização do solo urbano em meio a grandes incorporações imobiliárias. É importante considerar, em relação à legislação urbana do novo Plano Diretor (2020), que esses espaços livres não urbanizados figuram como áreas de "Parcelamento, Edificação ou Utilização Compulsórios", apontando a diretriz do novo plano como de constante expansão da mancha urbana.

Como pode ser observado no mapa da Figura 7, a expansão dos perímetros urbanos vem acompanhada do parcelamento do solo, empreendimentos públicos e privados são implantados convertendo áreas não urbanizadas em conjuntos habitacionais, condomínios horizontais fechados (loteamentos voltados a unidades residenciais de alto padrão construtivo) e grandes loteamentos formando, muitas vezes, novos bairros.

Em pesquisa documental sobre a cronologia de parcelamento do solo na cidade foi realizado um levantamento dos empreendimentos junto aos arquivos de projetos aprovados da Prefeitura Municipal de Campos dos Goytacazes. Cada projeto de parcelamento aprovado existente no arquivo foi sistematicamente fotografado, arquivado digitalmente e catalogado por área da cidade. Foi pos- sível, desta forma, identificar esses parcelamentos que marcam a expansão da mancha urbana.

As áreas parceladas pressionam as bordas da mancha urbana em um constante processo de expansão. Comparando as delimitações dos perímetros urbanos de 1991, 2008 e 2020, percebe-se o aumento da área urbana legalmente delimitada, prevendo expansão, em grande medida mantendo o estoque de espaços livres disponíveis ao parcelamento e edificação nas áreas de borda, sempre significativamente à frente da expansão real da mancha urbana.

É possível observar também, no mapa da Figura 7, a existência de ocupações irregulares, identificadas pelo censo (IBGE, 2010) como aglomerados subnormais, em rosa. Essas ocupações são, muitas vezes, objeto de remoções para conjuntos de habitação de interesse social, parte das políticas públicas possibilitadas pelo repasse de royalties e participações especiais da extração do petróleo na Bacia de Campos.

\section{O Ordenamento Urbano}

Como aponta Fernandes (2013), os agentes privados atuam de forma paralela, simultânea e articulada com os agentes públicos. Existe sintonia nos processos para definição de políticas e prioridades públicas, pois para a autora, o campo de ação corporativo é urbano e é também urbanístico, ou seja, atua para a definição das regras que definem o uso e a ocupação do solo urbano segundo seus interesses.

Os mapas da Figura 8 foram elaborados com base nas Leis:

- Lei Municipal n 7.947, de 2008 - Uso e Ocupação do Solo Urbano do Município de Campos dos Goytacazes - Em especial o Quadro $n^{\circ} 6$ do Anexo II - Índices e Parâmetros de Ocupação e o Mapa 01: Zoneamento Urbano do Distrito Sede e do Distrito de Goytacazes.

- Lei Complementar Municipal no 16, de 2020 - Uso e Ocupação do Solo Urbano do Município de Campos dos Goytacazes/RJ - Em especial o Quadro $n^{\circ} 6$ do Anexo II - Indices e Parâmetros de Ocupação e o Anexo III Mapa de Zoneamento Urbano do Distrito Sede. 


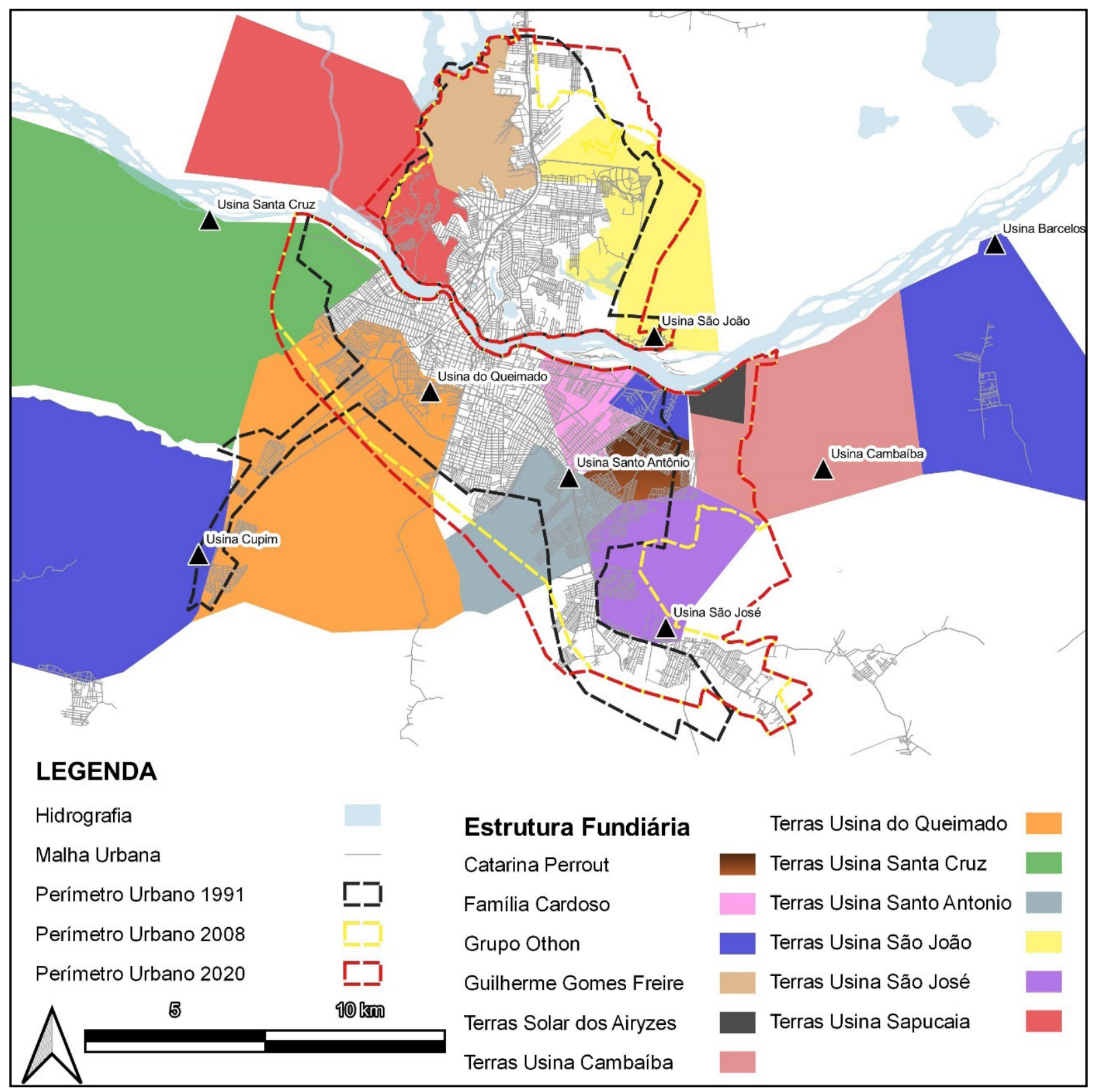

Figura 6: Mapa da Estrutura Fundiária

Mapa representando a estrutura fundiária do distrito sede de Campos dos Goytacazes e sua relação com a malha urbana e os perímetros urbanos delimitados.

Fonte: Elaborado pelos autores (2021) com dados de CONTI (2013), Aliprandi (2017), IBGE (2020), PMCG (2020). 


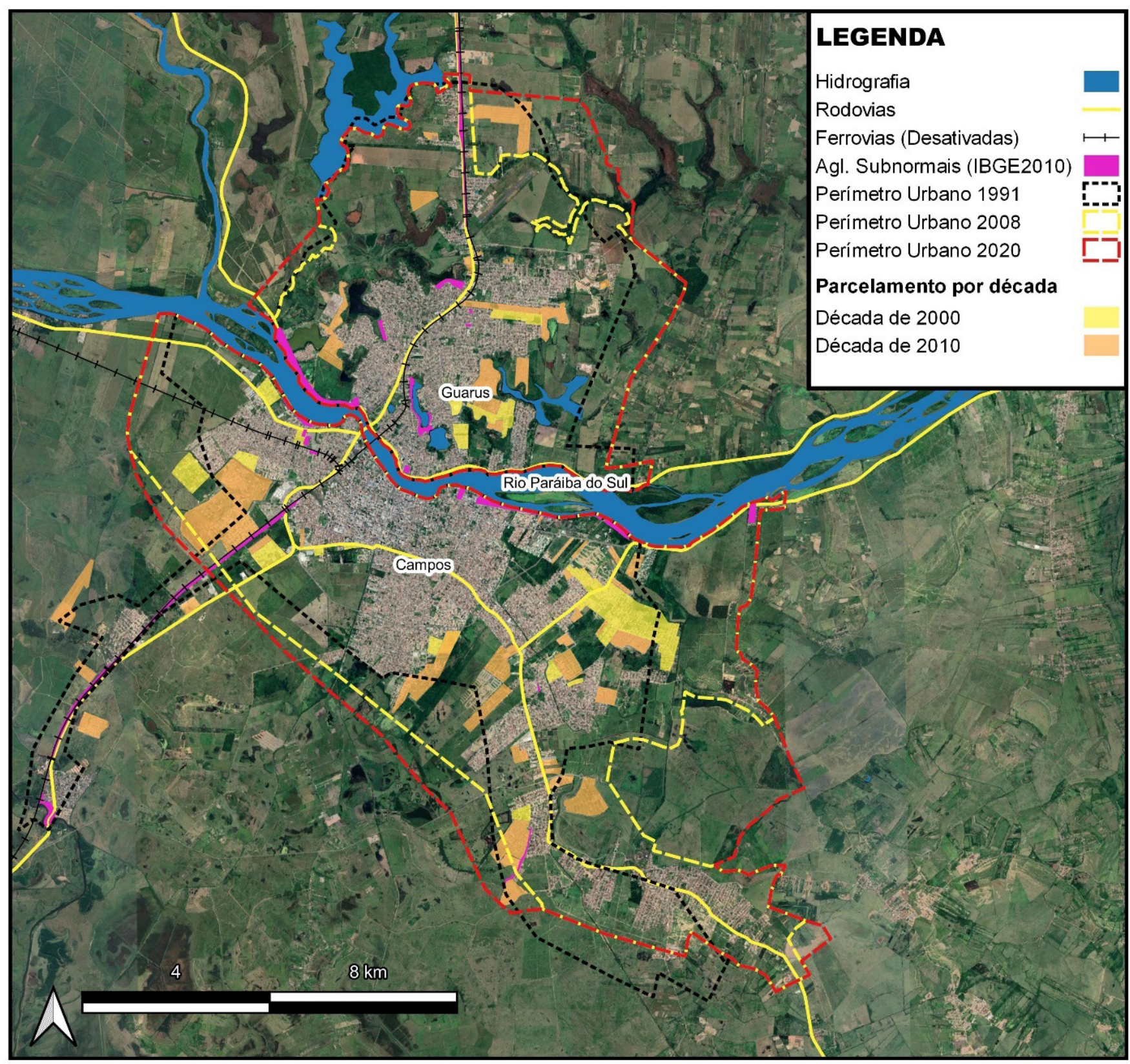

Figura 7: Parcelamento do Solo

Mapa representando o parcelamento do solo nas décadas de 2000 e 2010 no distrito sede de Campos dos Goytacazes

Fonte: Elaborado pelos autores (2021) com dados de Faria (1998), Aliprandi (2017), PMCG (2016-2020), IBGE (2010/2020), Google Earth (2019). 
Tais leis disciplinam o Coeficiente de Aproveitamento do Terreno $(\mathrm{CAT})^{1}$ e a Taxa de Ocupação do solo (TO $)^{2}$. Assim, o proprietário de um lote de $200 \mathrm{~m}^{2}$ localizado na Zona Residencial Um (ZR-1) com CAT 1,0 e TO $50 \%$, poderá construir um edifício de até $200 \mathrm{~m}^{2}$ que ocupe no máximo metade do terreno, ou seja, $100 \mathrm{~m}^{2}$. De outro modo, o proprietário de um lote de $200 \mathrm{~m}^{2}$ que esteja localizado ao longo de um Eixo de Comércio e Serviços Três (ECS3), cruzando uma Zona Residencial Quatro (ZR-4), teria permissão para construir sob parâmetros de CAT 5,0 e TO $80 \%$. Ou seja, poderia chegar a uma edificação de $1000,00 \mathrm{~m}^{2}$ e ocupar $80 \%$ da área do lote. Tais parâmetros de áreas superiores ao tamanho do lote são obtidos com gabaritos elevados, ou seja, com a construção de edifícios de vários pavimentos.

Ainda é importante ressaltar que, de acordo com a Lei Complementar Municipal $n^{\circ} 16$, de 2020, em seu Artigo 21, existem áreas construídas da edificação que não são contabilizadas no cálculo do Coeficiente de Aproveitamento. Note-se que tais áreas não são vendáveis como unidades autônomas, figuram essencialmente como áreas comuns nos edifícios, áreas técnicas, administrativas ou de garagem:

Subsolo, desde que totalmente enterrado ou semienterrado e que não ultrapasse em qualquer ponto $4,00 \mathrm{~m}$ (quatro metros) de altura em relação ao perfil natural do terreno (quando implantado sobre terreno em declive);

Áreas de recreação e lazer, mesmo que construídas, em prédios residenciais ou de uso misto cujo pavimento tipo tenha uso exclusivamente residencial, desde que não ultrapasse o total da área mínima exigida no código de obras; nos casos que se exceder a área mínima exigida, deve ser computava a área excedente;

1 O Coeficiente de Aproveitamento do Terreno (CAT) corresponde à relação entre a área total construída da edificação e a área total do terreno.

2 A Taxa de Ocupação do solo (TO) é o percentual de área do terreno que pode ser ocupado por edificação ou edificações.
Áreas complementares à atividade principal os serviços gerais e de apoio à edificação: Estacionamentos e garagens nos prédios residenciais; Estacionamentos nos prédios não residenciais, exceto edifícios - garagem; Reservatórios, casa de bombas, casa de máquinas de elevadores, área para depósito de lixo, transformadores, geradores, medidores, central de gás, centrais de ar condicionado; De uso comum, como portarias, acessos e circulações nos pilotis e nos pavimentos de uso comum, zeladoria e lazer.

Áreas de pilotis, desde que livres, ocupadas por garagem ou por estacionamento, excluídas as áreas citadas anteriormente.

Nesse contexto, os Índices e Parâmetros de Ocupação determinados pelas Leis de Uso e Ocupação do Solo são fundamentais para a determinação do valor da terra urbana, haja vista que a maior capacidade de construção sobre o lote implica a multiplicação de unidades vendáveis ou a possibilidade de empreendimentos imobiliários mais lucrativos.

A Lei de Uso e Ocupação do Solo ainda delimita em seu artigo 80:

O Setor Especial Institucional corresponde às áreas destinadas aos equipamentos urbanos e comunitários, tais como prefeitura, escolas, hospitais, delegacia e demais usos institucionais de caráter público, onde os parâmetros de ocupação devem ser mais flexíveis para atender às especificidades das edificações.

E em seu Artigo 85:

As Zonas de Expansão Urbana - ZEU, incluídas dentro da Macrozona de Expansão Urbana, compreendem as glebas de terra não parceladas, situadas na periferia da área urbana ocupada, para as quais deverão ser elaborados Planos de Ordenamento do Território - POT's que orientem o processo de sua urbanização. 
Ou seja, tais áreas não têm parâmetros necessariamente determinados, sendo necessários Planos de Ordenamento do Território POT's, sujeitos à aprovação para que o solo seja parcelado. Bem como os empreendimentos nessas áreas podem estar sujeitos à elaboração e aprovação do Estudo de Impacto de Vizinhança (EIV) e de parecer favorável do Instituto Municipal de Urbanismo - IMU.

A comparação exposta nos mapas da Figura 8, entre a legislação vigente a partir de 2008 e, posteriormente, a partir de 2020, tem por objetivo estabelecer uma relação entre esses dois momentos. Com um distanciamento temporal do início de suas vigências de 12 anos, também houve mudanças nos parâmetros de ocupação do território, além do aumento da área legalmente delimitada como perímetro urbano.

Ao analisar essas legislações de uso e ocupação do solo, fica claro que a estrutura de ambos segue o mesmo padrão de planejamento urbano, dividindo a cidade em zonas de ocupação conforme o uso e o impacto de suas atividades. Portanto, é possível, por meio da comparação visual entre os dois mapas, uma vez que os parâmetros das duas leis são praticamente iguais em suas definições quantitativas, construir uma percepção da expectativa de expansão urbana que o planejamento norteado por essas legislações aponta para Campos dos Goytacazes.

Observa-se que o viés de planejamento adotado é o da constante expansão da mancha urbana. Além do aumento significativo do perímetro urbano entre os anos de 2008 e 2020, os índices de ocupação do solo se intensificaram entre os dois períodos em direção às bordas do tecido urbano, preservando grande estoque de terras não parceladas inclusas no perímetro urbano, e estimulando seu parcelamento e edificação.

Importante a ser observado é que as mudanças mais significativas referentes ao aumento dos índices de uso e ocupação do solo ocorrem na margem sul do Rio Paraíba do Sul, mais atrativo ao investimento imobiliário. Enquanto na margem norte a mudança mais visível é o aumento das áreas de preservação. Também são delimitadas, de um plano para o outro, novas áreas de preservação e de recreação na margem sul, bem como definidos novos eixos já consolidados e projetados. O que se pode concluir é que tais mudanças são condizentes com um ordenamento que favorece os interesses dos agentes imobiliários, pois o aumento do perímetro urbano e dos parâmetros de ocupação permitem maior renda imobiliária.

\section{As Transformações da Paisagem}

Pode-se observar que a mancha urbana campista tem se tornado mais extensa. $O$ espraiamento urbano vem ocorrendo, conforme demonstrado, essencialmente por meio de empreendimentos imobiliários que parcelam o solo de antigas propriedades rurais, convertidas em terras urbanas pelo ordenamento dos planos municipais. O processo de expansão urbana das últimas décadas é caracterizado tanto com a ocorrência do padrão condominial de grandes loteamentos fechados de alto padrão construtivo, quanto de edifícios e conjuntos de edifícios residenciais, ou condomínios horizontais. Também se parcelou o solo em extensos loteamentos urbanos e em conjuntos de habitação de interesse social, expandindo as bordas do tecido urbano.

É possível observar em cinza no mapa da Figura 9 a grande quantidade de espaços livres não urbanizados, na verdade estoque de terras para parcelamento e edificação, constituindo, conforme o Plano Diretor, as Zonas de Expansão Urbana. Esses espaços livres de edificação e urbanização representam $34,53 \%$ de todo perímetro urbano legalmente delimitado em $2020,41,33 \%$ se for considerado apenas o subdistrito de Campos, na margem sul do rio.

Uma pequena parte desses espaços livres localizados na margem sul do rio é delimitada em verde na Figura 9, como setores especiais de recreação ou preservação. É interessante notar que, mesmo com o orçamento público diferenciado, desde a mudança na lei de repasses de royalties e participações especiais no fim da década de 1990, a cidade não conta com nenhum parque urbano de porte. O crescimento da mancha urbana não acompanhou a implantação de equipamentos dessa natureza, embora os Planos Diretores já reservem espaços destinados a esse fim. 


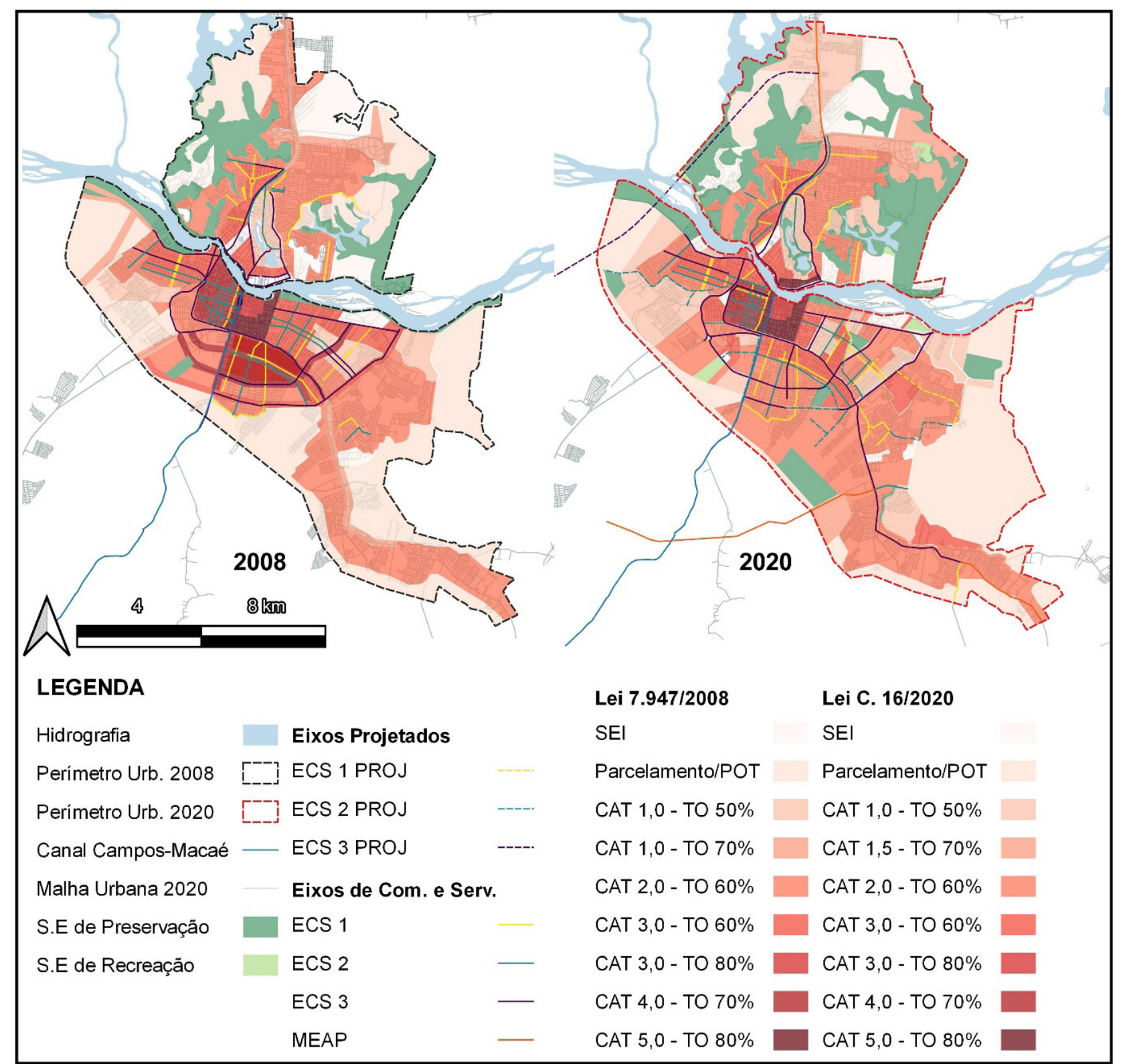

Figura 8: Comparativo da Legislação de uso do solo 2008/2020

Mapas representando a comparação entre as normas de uso e ocupação do solo dos Planos Diretores Municipais de 2008 e 2020, de Campos dos Goytacazes.

Fonte: Elaborado pelos autores (2021) com dados de PMCG (2008/2020), IBGE (2020), Google Earth (2020). 


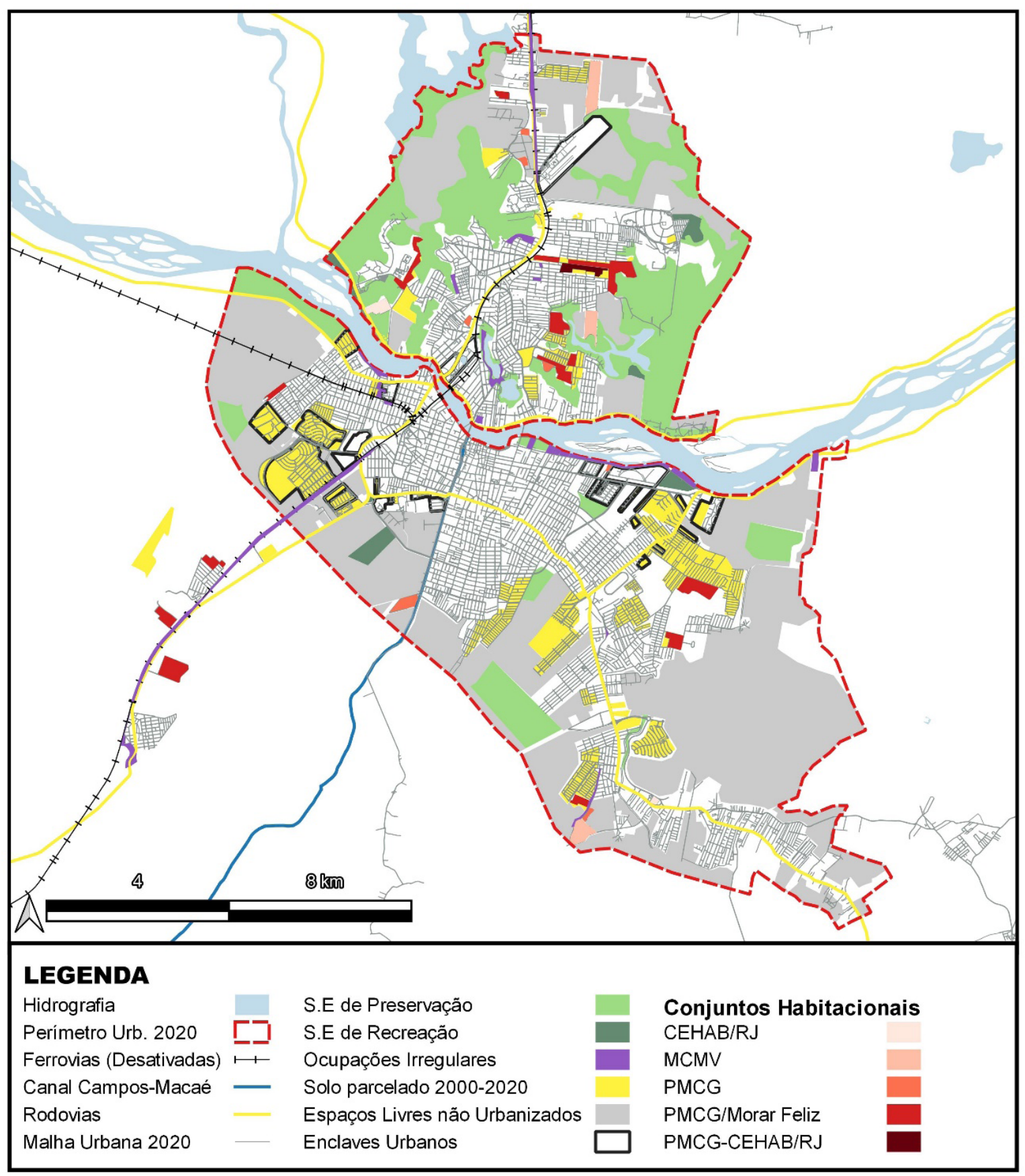

Figura 9: Transformações da paisagem

Mapa representando as transformações da paisagem nas bordas do tecido urbano na cidade de Campos dos Goytacazes.

Fonte: Elaborado pelos autores (2021) com dados PMCG (2016-2020), IBGE (2010/2020), Google Earth (2020). 
As ocupações irregulares, em roxo no mapa da Figura 9, geralmente se encontram em áreas de baixo controle fundiário, tensionando as áreas de proteção permanente, às margens de recursos hídricos, ferrovias ou rodovias. Assim, de acordo com a dinâmica das transformações e a implantação de empreendimentos imobiliários, as favelas campistas sofrem processos de remoção dentro dos programas de habitação social promovidos pelo poder público municipal, geralmente em direção às periferias da cidade e em grande medida para Guarus.

O volume da produção habitacional nas décadas de 2000 e 2010 não tem paralelo com outros períodos. A produção de conjuntos habitacionais de interesse social, por meio de fundos estaduais (CEHAB/RJ), federais (Programa Minha Casa, Minha Vida) e municipais (Programa Morar Feliz), é pujante. Os dados levantados nesta pesquisa apontam a construção de 11.254 unidades nos últimos 20 anos. Importante considerar o papel dos royalties e participações especiais da produção do petróleo no orçamento municipal que propiciou essa produção (D'ALMEIDA, 2018 e ARRUDA, 2014).

Essa realidade explicita a diferença na estruturação do tecido urbano entre os dois subdistritos, Campos e Guarus. O primeiro com solo de maior valorização e estruturação, com maior número de empreendimentos privados e menos áreas de preservação delimitadas. O segundo de menor estruturação urbana, concentrando a maioria dos conjuntos de habitação de interesse social, com menor interesse para o investimento privado e com maiores áreas de preservação delimitadas, embora tanto os conjuntos habitacionais quanto as ocupações irregulares produzam tensões quanto à ocupação dessas áreas preservadas. Como pode ser observado na Figura 10, alguns dos conjuntos habitacionais são implantados às margens das lagoas, no limite de sua faixa marginal de proteção, porém, ao longo do período após a ocupação, essas faixas não são necessariamente respeitadas.

É possível também observar a figura dos enclaves urbanos, em sua maioria resultantes dos processos de parcelamento do solo seguindo o padrão condominial, também demarcados no mapa da Figura 9. Dentre os enclaves, destacam-se os grandes loteamentos urbanos fechados, voltados à construção de edificações residenciais de alto padrão construtivo, os chamados condomínios fechados, que fragmentam o tecido urbano, diminuindo a fluidez da malha.

Na Figura 11 pode-se observar a área com a maior concentração desses tipos morfológicos, o setor oeste da cidade: [1] Condomínio Parthenon Park Residence; [2] Condomínio Athenas Park Residence; [3] Condomínio Royal Boulevard Premium; [4] Condomínio Damha I; [5] Condomínio Damha II; e [6] Condomínio Residencial Nashville Country. Para Caldeira (2011), são o dispositivo de uma nova maneira de organizar a segregação, a discriminação social e a restruturação econômica, juntamente com prédios de apartamentos, conjuntos de escritórios e shopping centers. Diferentes classes sociais vivem próximas umas das outras, mas são mantidas separadas por barreiras físicas e sistemas de identificação e controle.

Embora também possa ser considerado como uma região de grande atividade do mercado imobiliário, o setor sudeste não tem as mesmas características do setor oeste. Diante da demanda constante por novos loteamentos e da valorização do solo nos setores oeste e central, no início da década de 2000 ocorreu a implantação de novos bairros, e nos anos subsequentes das décadas de 2000 e 2010, esse setor passou por intensa atividade imobiliária destinada a faixas de renda e consumo diversificadas.

A relação entre as ações de agentes públicos e privados também resultou na construção e incorporação de diversos condomínios horizontais na cidade de Campos dos Goytacazes. Notoriamente financiados pelo programa Minha Casa, Minha Vida, a maior parte desses modelos foi implantada nas bordas urbanas do setor sudeste da cidade. Podemos destacar imagens aéreas de três exemplos na Figura 12: [1] O Mondrian Life (2013), com 624 unidades habitacionais, com financiamento MCMV-Faixa 2-3; [2] 0 Condomínio Terra Nova (2016), com 468 unidades habitacionais, com financiamento MCMV-Faixa 2; [3] Os Condomínios Vida Bela, Vida Boa e Viva Vida (2013/2014), com 220, 198 e 206 unidades habitacionais, respectivamente, com financiamento MCMV-Faixa 2-3. Alguns exemplos incluem unidades unifamiliares, ou casas geminadas, como é o caso dos exemplos 2 e 3 na Figura 12. Outras implantações correspondem a conjuntos de edifícios de até quatro pavimentos, sem a implantação de elevadores, pois a legislação 


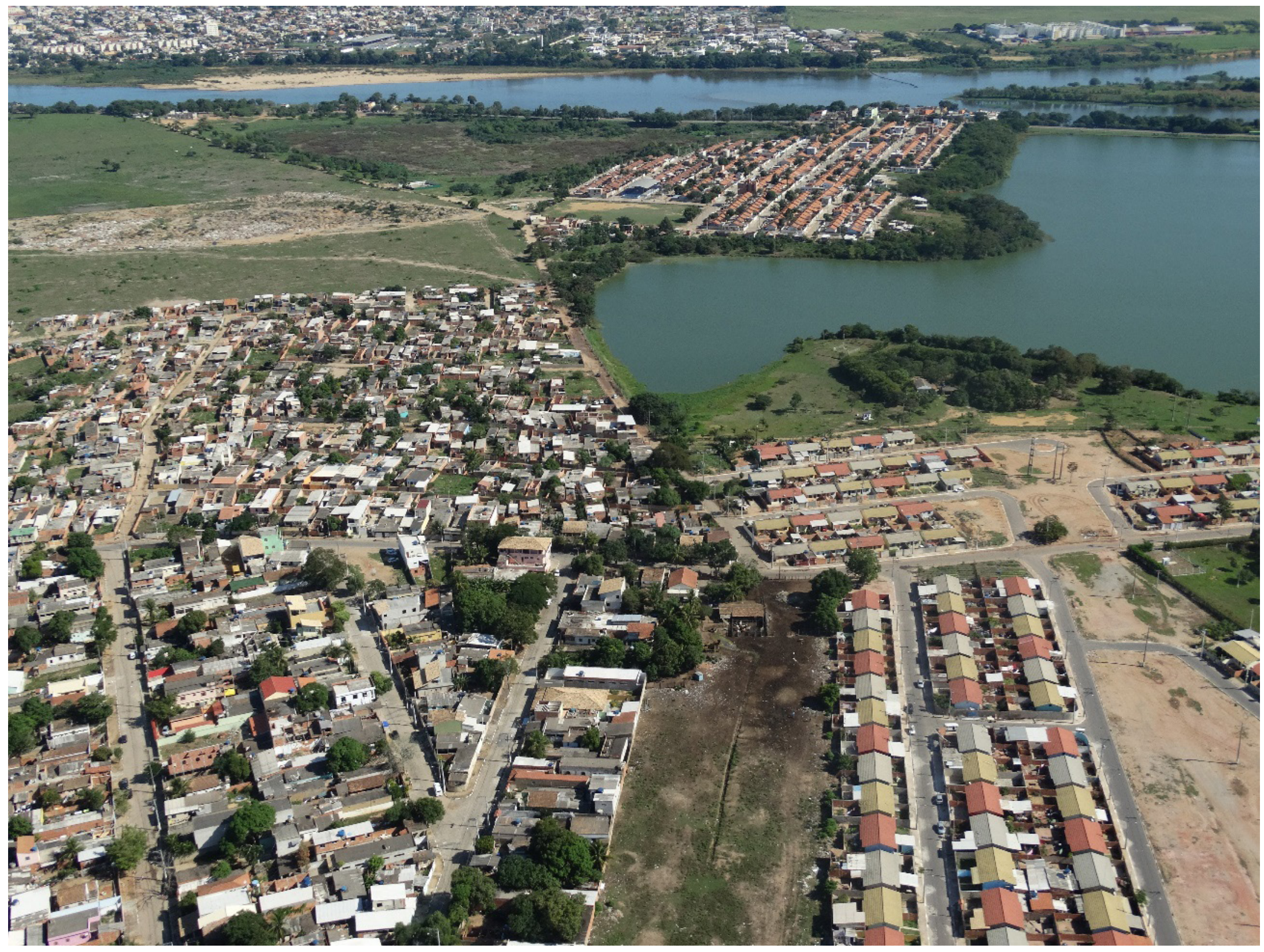

Figura 10: Ocupação das margens das lagoas em Guarus

Ocupação nas Margens de Lagoas - Guarus.

Fonte: Oficina QUAPÁ SEL, Campos dos Goytacazes (2015). 


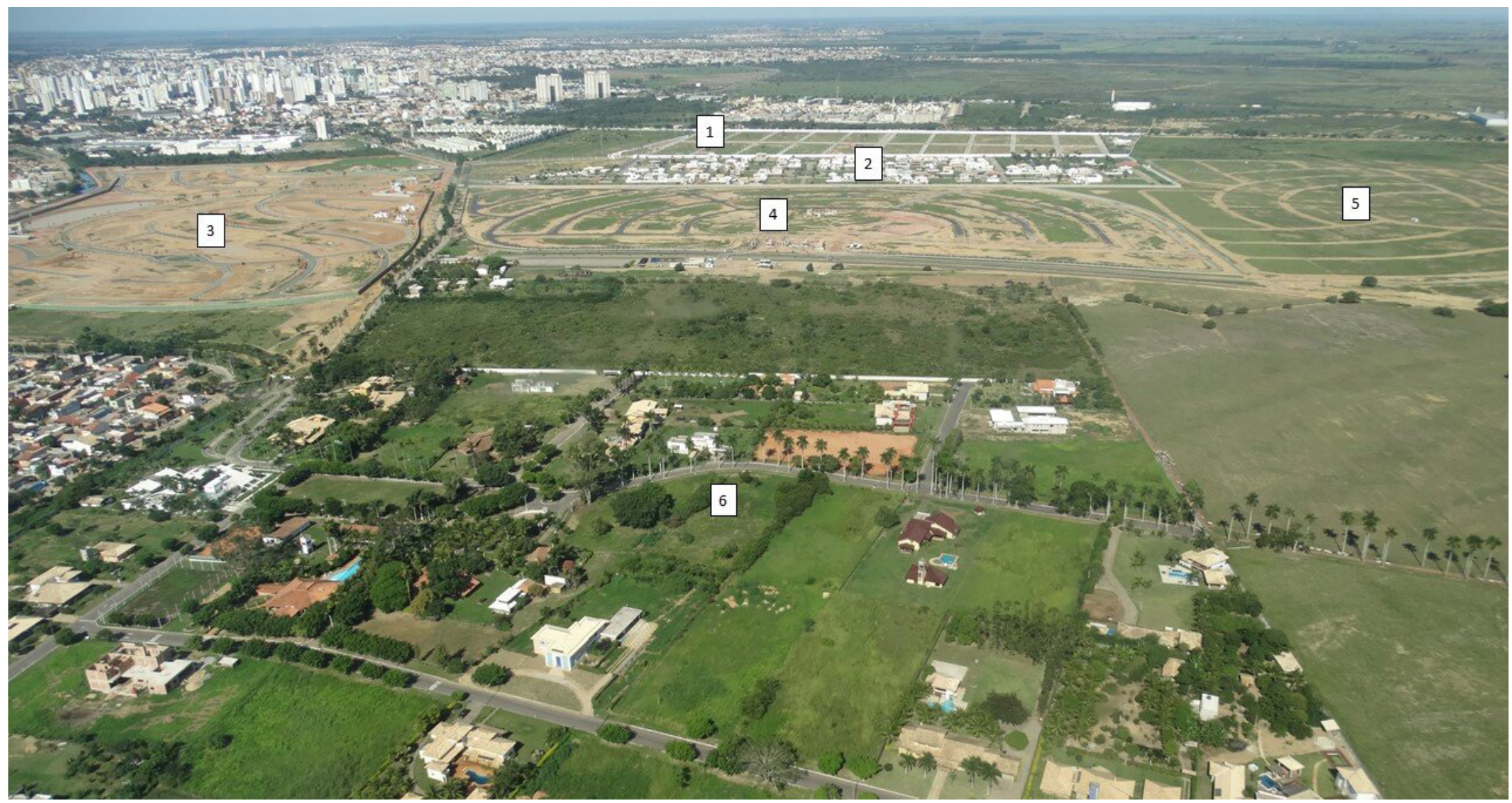

Figura 11: Condomínios Fechados

Condomínios Fechados - Setor Oeste.

Fonte: Oficina QUAPÁ SEL, Campos dos Goytacazes (2015) - Modificada pelos autores (2021).

municipal assim permite para edificações residenciais desse porte, caso do exemplo 1 da Figura 12.

\section{Considerações Gerais}

Podemos então concluir que o ordenamento urbano municipal, em especial a legislação de uso e ocupação do solo regulamentada a partir dos Planos Diretores (2008 e 2020), vem sendo produzido em sintonia com os interesses dos agentes imobiliários. Todo o potencial resultante de uma extensa planície rica em recursos ambientais e da autonomia financeira municipal propiciada pelos repasses de royalties produzem, na verdade, processos de fragmentação urbana e de periferização das populações de menor renda.

A legislação de uso e ocupação do solo estabelecida nesse período tem papel importante nesse processo, pois favorece a constante expansão do tecido urbano em paralelo à implantação de conjuntos de habitação de interesse social, cada vez mais localizados nas periferias menos estruturadas. A valorização do solo nessas áreas de interesse do mercado contribui para o processo de segregação socioespacial das populações de menor renda, cada vez mais peri- 

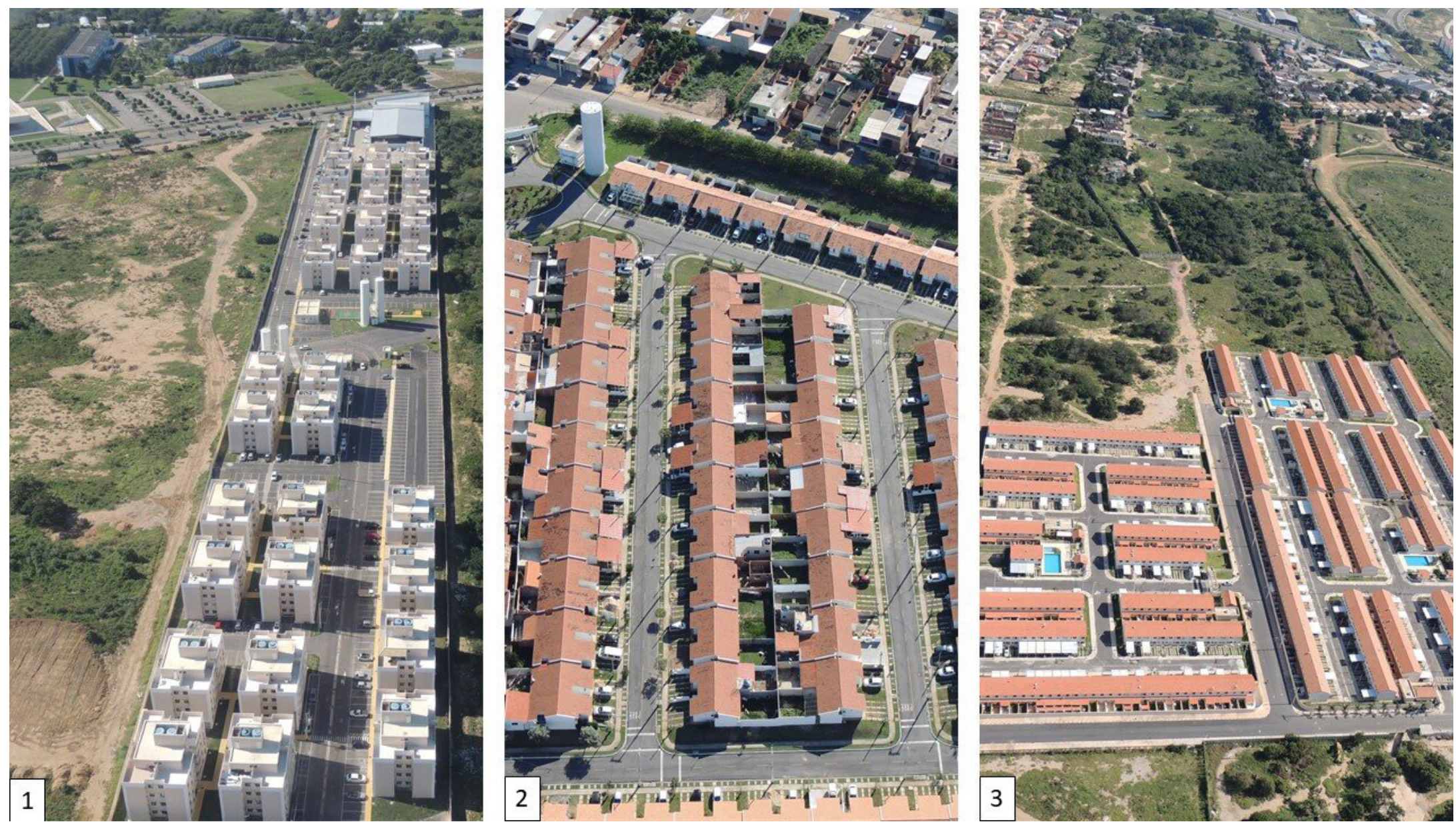

Figura 12: Condomínios Horizontais

Condomínios Horizontais - Setor Sudeste.

Fonte: Oficina QUAPÁ SEL, Campos dos Goytacazes (2015) - Modificada pelos autores (2021).

ferizadas. As distâncias se traduzem em tempo e em aumento dos custos de transporte para os moradores dessas áreas periféricas, aliadas à menor estruturação urbana e à precarização da moradia.

Embora o discurso da elaboração dos Planos Diretores Participativos de Campos dos Goytacazes seja o de cumprimento dos princípios constitucionais e do Estatuto da Cidade, em especial as funções sociais da propriedade e da cidade, o que se verifica, para além de suas letras iniciais, é a consolidação de uma legislação de uso e ocupação do solo que aponta para a hegemonia dos interesses do mercado imobiliário. Dessa forma, quem de fato ganha com as mudanças no ordenamento urbano, a expansão gradativa da superfície do perímetro urbano e o potencial de adensamento construtivo em diversas áreas são os grandes proprietários de terras e os agentes do mercado imobiliário. 


\section{Referências Bibliográficas}

AEQUUS CONSULTORIA. (Comp.). Compara Brasil. Vitória/ES. 2019. Disponível em: comparabrasil.com. Acesso em: 22 mai. 2019

ALIPRANDI, Danielly Cozer. O sistema de espaços livres da cidade de Campos dos Goytacazes/RJ: Carências e Potencialidades. 2017. 376 f. Tese (Doutorado em Arquitetura) - UFRJ/FAU, PROARQ, Universidade Federal do Rio de Janeiro, Rio de Janeiro, 2017.

ARRUDA, Ana Paula Serpa Nogueira de. Política habitacional e direito à cidade: a experiência do programa morar feliz em Campos dos Goytacazes-RJ. 2014. 274 f. Tese (Doutorado em Sociologia Política) Centro de Ciências do Homem, UENF, Campos dos Goytacazes, 2014

BRASIL. Constituição da República Federativa do Brasil de 1988. Brasília, DF: Presidência da República. 1988. Disponível em: http://www.planalto.gov.br/ccivil_03/constituicao/constituicao.htm. Acesso em: 16 jul. 2019.

BRASIL. Lei Federal No 9478, de 6 de agosto de 1997. Dispõe Sobre A Política Energética Nacional, As Atividades Relativas Ao Monopólio do Petróleo, Institui O Conselho Nacional de Política Energética e A Agência Nacional do Petróleo e Dá Outras Providências. Disponível em: https://www2.camara.leg.br/legin/fed/lei/1997/lei-9478-6-agosto1997-365401-publicacaooriginal-1-pl.html. Acesso em: 16 jul. 2019.

BRASIL. Estatuto da Cidade. 3. ed. Brasília: Senado Federal, Subsecretaria de Edições Técnicas, 2008. $102 \mathrm{p}$.

CALDEIRA, Teresa Pires do Rio. Cidade de muros: crime, segregação e cidadania em Săo Paulo. 3 ed. Traduçăo

CAMPOS DOS GOYTACAZES. Lei Municipal No 7.972. Plano Diretor Participativo do Município de Campos dos Goytacazes. 2008.

CAMPOS DOS GOYTACAZES. Lei Orgânica, de 15 de julho de 2014. Lei Orgânica do Município de Campos dos Goytacazes/RJ. Campos dos Goytacazes, 2014.

CAMPOS DOS GOYTACAZES. Lei Complementar Municipal Nº015, de 07 de janeiro de 2020. Institui o Plano Diretor do Município de Campos dos Goytacazes e dá outras providências. Campos dos Goytacazes, 2020.

CAMPOS DOS GOYTACAZES. Lei Complementar Municipal № 0016, de 07 de janeiro de 2020. Institui a lei de uso e ocupação do solo urbano do município de Campos dos Goytacazes/RJ. Campos dos Goytacazes, 2020.

CAMPOS DOS GOYTACAZES. CIDAC. 2019. Disponível em: https://cidac.campos.rj.gov.br/ servicos/inscricoes/revisao-do-plano-diretor-participativo-e-elaboracao-do-plano-de-mobilidade-sustentavel/. Acesso em: 26 jul. 2019.

CAPEL, Horacio. La Morfología de las Ciudades: III. agentes urbanos y mercado inmobiliario. Barcelona: Ediciones del Serbal, 2013. 462 p. (Colección La estrella polar).

CARDEMAN, Rogerio Goldfeld. A transformação da paisagem em área de expansão urbana: planejamento em vargem grande na cidade do Rio de Janeiro. 2014. $290 \mathrm{f}$. Tese (Doutorado em Arquitetura) - PROARQ-FAU-UFRJ, Rio de Janeiro, 2014.

COELHO, Leonardo Loyolla. Os conceitos de dispersão e fragmentação urbana sob a abordagem da paisagem. In: Encontro da Associação Nacional de Pesquisa e Pós-Graduação em Arquitetura e Urbanismo, 4., 2016, Porto Alegre. Anais... 2016, p 1-16

CONTI, Eliane França. Os vazios urbanos e a função social da propriedade: o papel do plano diretor do município de Campos dos Goytacazes/2008. 2013. 157 f. Disser- tação (Mestrado em Políticas Sociais). Centro de Ciências do Homem, Universidade Estadual do Norte Fluminense Darcy Ribeiro, Campos dos Goytacazes, 2013.

CRUZ, José Luis Vianna da; SHIMODA, Eduardo (Ed.). Info Royalties: Indicadores. 2019. Universidade Cândido Mendes. Disponível em: https://inforoyalties.ucam-campos.br/. Acesso em: 22 mai. 2019.

D'ALMEIDA, Ursula Gonçalves. A materialidade das políticas habitacionais na produção do espaço urbano em Campos dos Goytacazes/RJ. 2018. $170 \mathrm{f}$. Dissertação (Mestrado em Urbanismo). PROURB, Universidade Federal do Rio de Janeiro, Rio de Janeiro, 2018

FARIA, Teresa de Jesus Peixoto. Campos dos Goytacazes: Resourses et virtualités d'uneville brésilienne: données de I'histoire. EHESS, Paris, França, 1998. Tese (Doutorado em Études Urbaines) - Ecole des Hautes Etudes en Sciences Sociales, 1998.

FARIA, Teresa de Jesus Peixoto; ZACCHI, Raquel Callegario; MOTHÉ, Natália Guimarães. Desenvolvimento econômico, desigualdades e injustiças socioespaciais em Campos dos Goytacazes. O papel das políticas públicas urbanas. In: CASIMIRO, Balsa et. al. (Coord.) Ação Pública e Problemas Sociais em Cidades Intermediárias. Lisboa, 2013

FERNANDES, Ana. Decifra-me ou te devoro: urbanismo corporativo, cidade-fragmento e dilemas da prática do urbanismo no Brasil. In: GONZALES, Suely F. N.; FRANCISCONI, Jorge Guilherme; PAVIANI, Aldo (Org.). Planejamento e urbanismo na atualidade brasileira. São Paulo: Livre Expressão, 2013. p. 83-108.

GODOY, Antonio Leandro Crespo de; ALIPRANDI, Danielly Cozer. O Rio Paraíba do Sul como fronteira no tratamento desigual dos espaços livres públicos na cidade de Campo das Goytacazes/RJ. Encontro Nacional de Ensino de Paisagismo em Escolas de Arquitetura e Urbanismo do Brasil: Paisagismo necessário - verde social, 13., Anais [...]. Salvador/BA, p. 632-645, 2016

IBGE - Instituto Brasileiro de Geografia e Estatística. Ministério da Economia. Censo demográfico 1991: resultados do universo relativos as características da população e dos domicílios. 1991. Disponível em: https://biblioteca.ibge.gov.br/biblioteca-catalogo?i$d=782$ \&view $=$ detalhes. Acesso em: 20 jan. 2021.

IBGE - Instituto Brasileiro de Geografia e Estatística. Ministério da Economia. Censo demográfico 2010. Disponível em: https://censo2010.ibge.gov.br/. Acesso em: 20 jan. 2021 IBGE - Instituto Brasileiro de Geografia e Estatística. Ministério da Economia. Sistema IBGE de Recuperação Automática - SIDRA: bancos de tabelas estatísticas. Bancos de Tabelas Estatísticas. 2020. Disponível em: https://sidra.ibge.gov.br/. Acesso em: 30 set. 2020

IBGE - Instituto Brasileiro de Geografia e Estatística. Ministério da Economia. Campos dos Goytacazes: panorama. 2020. Disponível em: https://cidades.ibge.gov.br/brasil/rj/ campos-dos-goytacazes/panorama. Acesso em: 01 jul. 2020

MACEDO, Silvio Soares. Quadro do paisagismo no Brasil: 1783-2000. 2. ed. São Pau lo: Editora da Universidade de São Paulo, 2015. 148 p.

MACEDO, Silvio Soares et al. Os sistemas de espaços livres e a constituição da esfera pública contemporânea no Brasil. São Paulo: Editora da Universidade de São Paulo, 2018. 416 p.

MAGNOLI, Miranda Martinelli. Espaço livre: objeto de trabalho. Paisagem e Ambiente, São Paulo, v. 21, p.157-197, 2006. Disponível em: https://doi.org/10.11606/issn.23595361.v0i21p175-197. Acesso em: 04 ago. 2019.

NADALIN, Vanessa; IGLIORI, Danilo. Espraiamento urbano e periferização da pobreza na região metropolitana de São Paulo: evidências empíricas. Eure (Santiago), Santiago, v. 41, n. 124 , p. $91-111$, set. 2015. 
NANDIN, Cauana Lemes Conde. Urbanização, dispersão e morfologia urbana: um estudo de caso na região metropolitana de campinas. 2013. 80 f. Dissertação (Mestrado em Urbanismo) - Centro de Ciências Exatas, Ambientais e de Teconologias, Puc-Campinas, Campinas, 2013.

OLIVERIA, Maria Lima de. Renovação Viária de Campos dos Goytacazes: Uma proposta retomada. Dissertação (Mestrado em Engenharia Urbana) - Universidade Federal do rio de Janeiro. Escola Politécnica. 2012. 118f.:85il.

REIS, Nestor Goulart. Dispersão urbana e modernização capitalista. Revista Cidades: Urbanização Difusa, São Paulo, v. 12, n. 21, p. 91-107, 2015. Disponível em: https:// revista.fct.unesp.br/index.php/revistacidades/issue/view/285. Acesso em: 05 set. 2021.

RIO DE JANEIRO. Secretaria Geral de Planejamento. Tribunal de Contas do Estado do Rio de Janeiro. Estudos Sócio Econômicos: Campos dos Goytacazes. 2019. Disponível em: http://www.tce.rj.gov.br/web/guest/estudos-s/ 2019.

SANTOS, Milton. A Natureza do Espaço: Técnica e Tempo, Razão e Emoção - 4. ed. 2. reimpressão. - São Paulo: Editora da Universidade de São Paulo, 2006. - (Coleção Milton Santos; 1)

SANTOS JUNIOR, Wilson. R. D. Os projetos estratégicos e a reestruturação do território. Conflitos e potencialidades na Região Metropolitana de Campinas. Encontro Nacional da Associação Nacional de Pós-Graduação e Pesquisa em Planejamento Urbano e Regional, 14.,2011 Anais... Rio de Janeiro: [s.n.]. 2011. p. 1-17.

ZACCHI, Raquel Callegario. O papel dos proprietários fundiários e do estado no processo de conversão de terras rurais em urbanas e na produção de loteamentos fechados: Campos dos Goytacazes/RJ (1980-2011). 170 f. Dissertação (Mestrado em Políticas

Sociais) - Centro de Ciências do Homem, UENF, Campos dos Goytacazes, 2012.

\section{Antonio Leandro Crespo de Godoy}

Instituto Federal de Educação, Ciência e Tecnologia Fluminense Rua Dr. Siqueira, 273 - Parque Dom Bosco, 28030-130, Campos dos Goytacazes, RJ, Brasil

https://orcid.org/0000-0001-9198-9843

antoniolcg@gmail.com

\section{Vera Regina Tângari}

Universidade Federal do Rio de Janeiro. Faculdade de Arquitetura e Urbanismo.

Av. Pedro Calmon, 550/sl. 433 - Prédio da Reitoria, Ilha do Fundão -

Rio de Janeiro - RJ 21941-590

https://orcid.org/0000-0003-4608-7909

vtangari@gmail.com

\section{Notas do editor:}

Data de submissão: 15/04/2021

Aceite: 19/09/2021

Revisão: RMO 